\title{
Viral gametocytic hypertrophy of Crassostrea gigas in France: from occasional records to disease emergence?
}

\author{
Céline Garcia ${ }^{1, *}$, Maeva Robert ${ }^{1}$, Isabelle Arzul ${ }^{1}$, Bruno Chollet $^{1}$, Jean-Pierre Joly ${ }^{1}$, \\ Laurence Miossec ${ }^{1}$, Thierry Comtet ${ }^{2}$, Franck Berthe ${ }^{1,3}$
}

${ }^{1}$ Laboratoire de Génétique et de Pathologie, IFREMER, Station de La Tremblade, Ronce les Bains, BP 133, 17390 La Tremblade, France

${ }^{2}$ Centre National de la Recherche Scientifique (CNRS) 7127, Equipe Ecologie Benthique, Station Biologique, BP 74, 29682 Roscoff Cedex, France

${ }^{3}$ Department of Pathology \& Microbiology, Atlantic Veterinary College, University of Prince Edward Island (UPEI), 550 University Ave., Charlottetown C1A 4P3, Canada

\begin{abstract}
Viral gametocytic hypertrophy was reported for the first time in 2001 in Pacific oyster Crassostrea gigas in France. Since this date, the number of reported cases and the distribution area have increased every year; however, the cases are not associated with macroscopic signs or increased mortality rates. Both male and female gametes were hypertrophied and basophilic inclusions were observed in gamete nuclei. Transmission electron microscopy revealed the presence of viral particles in these intranuclear basophilic inclusions. These particles had characteristics similar to those of the Papillomaviridae and Polyomaviridae families: they were small, non-enveloped, icosahedral, and 44 to $56 \mathrm{~nm}$ in diameter. The viral particles were found in male, female and hermaphrodite oysters and no significant difference in viral infection was observed between those groups. The frequency of detection and the intensity of infection were low and no host defence reaction was recognised, suggesting that the viral particles had a weak impact on C. gigas. The viral particles described in the present study seem to be similar to these described in $C$. virginica in the USA and Canada and in C. gigas in Korea, but further studies are required to confirm their identity. The issue of a possible emergence of this infection is discussed.
\end{abstract}

KEY WORDS: Crassostrea gigas - Pacific oyster - Viral gametocytic hypertrophy · Gonad · Papillomaviridae $\cdot$ Polyomaviridae

\section{INTRODUCTION}

Since the 1970s, viruses belonging to various families have been reported in bivalve molluscs: Herpesviridae, Iridoviridae, Picornaviridae, Reoviridae, Birnaviridae, Retroviridae and Papovaviridae (Elston 1997). This last family was originally composed of the 2 genera, Papillomavirus and Polyomavirus, which are now recognized as 2 separate families, Papillomaviridae and Polyomaviridae (Van Regenmortel et al. 2000). These 2 families share morphological characteristics: they are viruses which are non-enveloped, icosahedral, and 40 to $55 \mathrm{~nm}$ in diameter. Replication and assembly occur in the nucleus of the host cell and virions are released by cell destruction. Members of the families Papillomaviridae and Polyomaviridae are generally host-specific and are transmitted by contact or by airborne particles. Many have been reported as oncogenic (Van Regenmortel et al. 2000). They infect a wide range of animals including marine vertebrates and invertebrates (Farley 1976, Edwards et al. 1977).

A papilloma-like virus responsible for viral gametocytic hypertrophy (VGH) was first reported in 1973 in adults of the eastern oyster Crassostrea virginica collected in the USA from Maine (Farley 1976). Similar viral particles were also observed in C. virginica on the east coast of North America (Sparks 1985), from the Gulf of Mexico (Winstead \& Courtney 2003) and from Atlantic Canada (McGladdery \& Stephenson 1994). Papillomalike or polyoma-like viruses were detected in other bi- 
valve species such as Mya arenaria in Massachusetts (USA), Pinctada maxima in Australia, Ruditapes philippinarum in Spain (Elston 1997, Montes et al. 2001) and more recently in C. gigas in Korea (Choi et al. 2004).

Bivalve papilloma-like and polyoma-like viruses apparently induce hypertrophy of the host cell nucleus associated with dense nucleic inclusions. Viral particles have been observed in haemocytes, connective tissues and gill epithelium of Mya arenaria; in labial palps epithelial cells of Pinctada maxima; in gill epithelium, striated muscular fibres, neurons, granulocytes, endothelium and connective tissue of Ruditapes philippinarum and in gametocytes of Crassostrea virginica and C. gigas (Elston 1997, Montes et al. 2001, Choi et al. 2004). Similar gametocyte lesions have been reported in several ostreid species such as Saccostrea glomerata, $C$. rhizophorae, Ostrea edulis and $O$. conchaphila $(=O$. lurida), but the presence of viral particles was not confirmed by transmission electron microscopy (TEM) (Farley 1978, Bower et al. 1994). From these reports, it is difficult to assess the actual impact of papilloma-like and polyoma-like viruses on their molluscan host. Another pending question is whether or not reported infections of molluscs are caused by a unique virus. We report here the presence of VGH in French populations of Pacific oyster Crassostrea gigas. drated, cleared twice in propylene oxide for $15 \mathrm{~min}$ and infiltrated for $1 \mathrm{~h}$ in 50:50 propylene oxide:Epon resin. After $1 \mathrm{~h}$ infiltration in pure Epon resin, they were embedded in resin and cured for $48 \mathrm{~h}$ at $60^{\circ} \mathrm{C}$. Ultrathin (20 nm thick) sections were stained in 5\% uranyl acetate in $50 \%$ ethanol for $20 \mathrm{~min}$ and in $5 \%$ lead citrate in fresh boiled distilled water for $3 \mathrm{~min}$. They were examined with a JEOL JEM 1200 EX transmission electron microscope at $80 \mathrm{kV}$.

The infection frequency is defined as the proportion of infected individuals in a given sample (Ancelle 2002). Frequencies of the infection in male and female oysters were compared using a $\chi^{2}$ test (Scherrer 1984). Only the years 2002 to 2004 were considered because samples were comparable and representative.

\section{RESULTS}

From 2001 to 2004, 36 individuals displayed gonadal lesions that were characterised by an abnormally increased size of gametes. Ovocyte size could reach $100 \mu \mathrm{m}$ in diameter (normal size of a ripe ovocyte: $36 \pm$ $4.4 \mu \mathrm{m}$; Lango-Reynoso et al. 2000), and spermatozoa could reach $52.1 \mu \mathrm{m}$ in head diameter (normal size of a mature spermatozoa without flagella: $2.5 \mu \mathrm{m}$ in diame-

\section{MATERIALS AND METHODS}

From 2001 to 2004, 156 samples of Crassostrea gigas, making a total of 3980 individuals, were collected along French coasts as part of the national zoosanitary surveillance programme (Fig. 1). Out of these 156 samples, 76 were spat and 80 were adults.

Oyster individuals were cut into 2 parts; one was fixed in Davidson's fixative for histological examination and the other was fixed in Carson's fixative for further TEM. Tissues in Davidson's fixative were dehydrated and embedded in paraffin. Two sections per individual ( 2 to $3 \mu \mathrm{m}$ thick) were cut; the first was stained with hematoxylin-eosin for routine examination and the second with Feulgen's stain for DNA when lesions were present.

The Carson-fixed tissues were transferred into cold $2.5 \%$ glutaraldehyde in $0.2 \mathrm{M}$ cacodylate buffer at $\mathrm{pH} 7.2$ for $1 \mathrm{~h}$ and rinsed twice in $0.2 \mathrm{M}$ cacodylate buffer at $4^{\circ} \mathrm{C}$ for $48 \mathrm{~h}$. Tissues were then postfixed twice in $1 \%$ osmium tetroxide in the same buffer at $4^{\circ} \mathrm{C}$ for $10 \mathrm{~min}$. They were dehy-

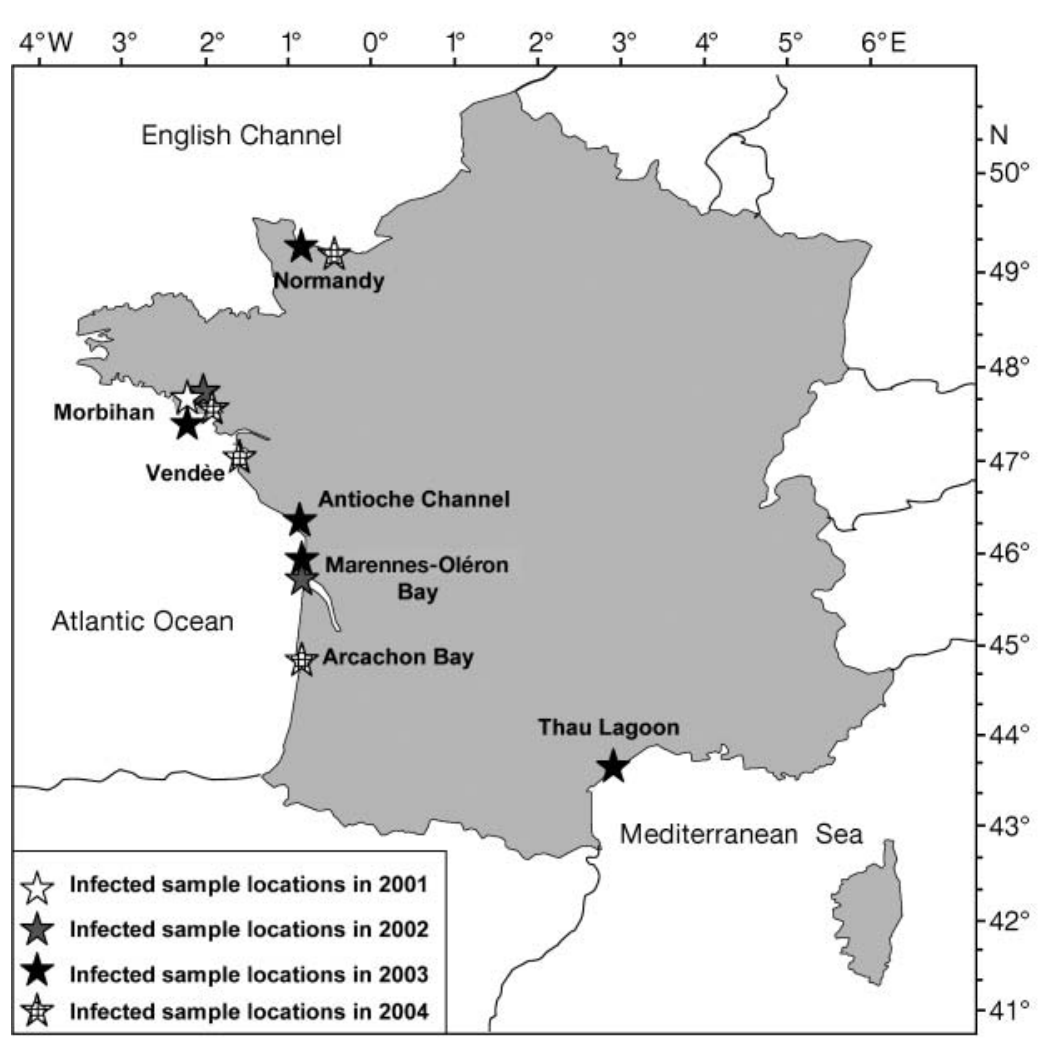

Fig. 1. Location of the infected Crassostrea gigas samples in France collected between 2001 and 2004 


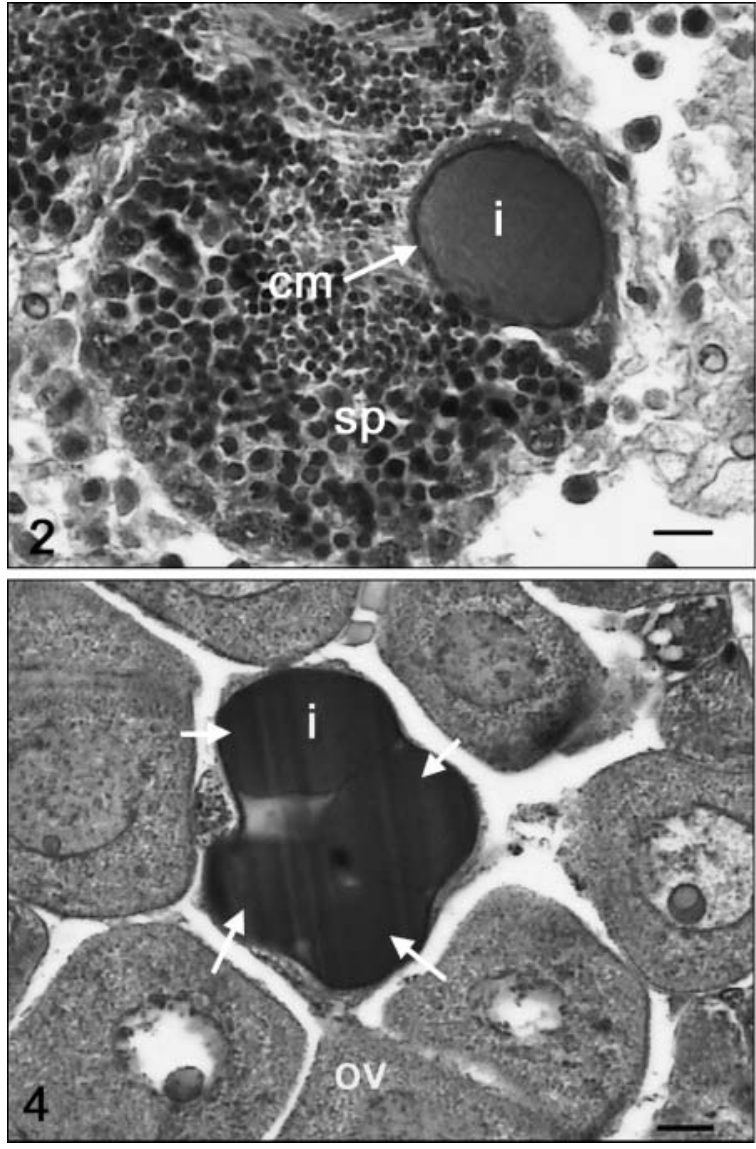

ter; Bozzo et al. 1993). In hematoxylin-eosin-stained sections, infected male and female gametes exhibited basophilic hypertrophied nuclei with perinuclear condensed material (Figs. 2 \& 3). An amorphous matrix, corresponding to a basophilic finely granulous inclusion, was observed in the central area of abnormal nuclei (Fig. 2). Cytoplasm was frequently reduced due to nucleus hypertrophy (Fig. 3). One female oyster showed 4 inclusions in a single ovocyte nucleus (Fig. 4). Inclusions in both ovocytes and spermatozoa were moderately Feulgen-positive, indicating the presence of DNA (Fig. 5) whereas the perinuclear condensed material was strongly Feulgen-positive. In all cases, no major haemocyte infiltration or other lesions were found associated with the infection.

At the ultrastructural level, nuclear membranes of infected gametes appeared normal and an interrupted ring of marginated chromatin was observed; the central area of infected nuclei contained numerous viral particles (Fig. 6). Viral particles were non-enveloped and small; their size varied between 44 to $56 \mathrm{~nm}$ in diameter (average $48 \pm 1 \mathrm{~nm}$ ). They showed 5 or 6 sides in section, suggesting an icosahedral symmetry (Fig. 7). Both empty and full capsids could be observed (Fig. 8). Viral particles were also detected in extracellular spaces of

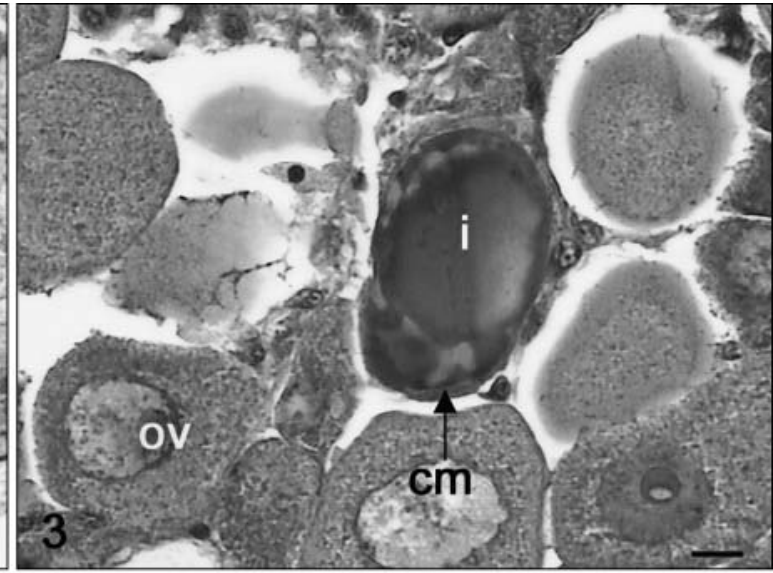

Figs. 2 to 4. Crassostrea gigas. Intranuclear inclusions in gametes of the oyster. Hematoxylin-eosin-stained histological sections of gonadal tissue (scale bars = $10 \mu \mathrm{m})$. Fig. 2. Inclusion (i) and perinuclear condensed material $(\mathrm{cm})$ in the nucleus of a spermatozoon (sp). Fig. 3. Inclusion (i) and perinuclear condensed material $\overline{(\mathrm{cm})}$ in the nucleus of an ovocyte (ov). Fig. 4. Four inclusions ( $i$, see arrows) in the nucleus of an ovocyte (ov)

the gonad follicles (Fig. 9). No cytoplasmic abnormality could be observed in ovocytes or spermatozoa.

The infection intensity was generally low with an average of 16 infected gametes per slide (1 to 136 infected cells per section). The frequency of

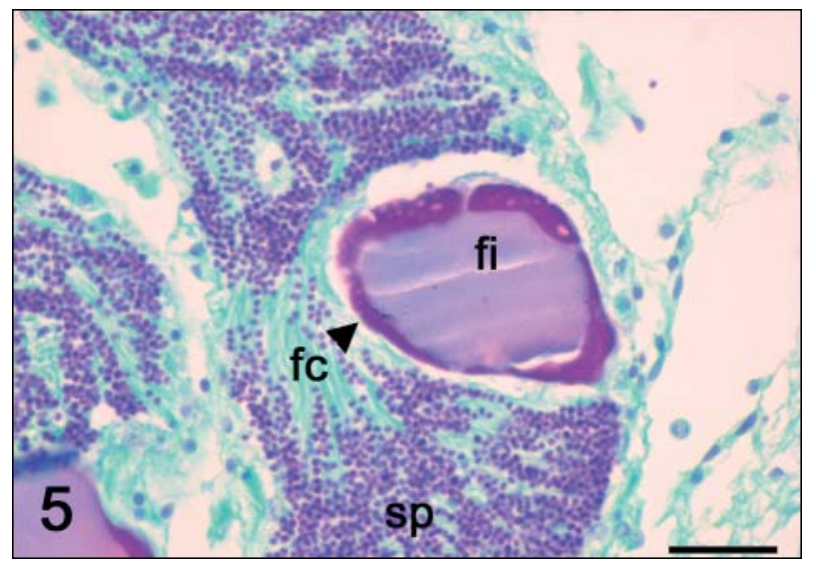

Fig. 5. Crassostrea gigas. Intranuclear inclusions in a spermatozoon of the oyster. Feulgen-stained histological section of gonadal tissue (scale bar $=20 \mu \mathrm{m})$. Moderate Feulgen-positive inclusions (fi) in the nucleus centre and strong Feulgenpositive condensed material ( $\mathrm{fc}_{\mathrm{r}}$, see arrowhead) at the nucleus periphery of a spermatozoon (sp) 

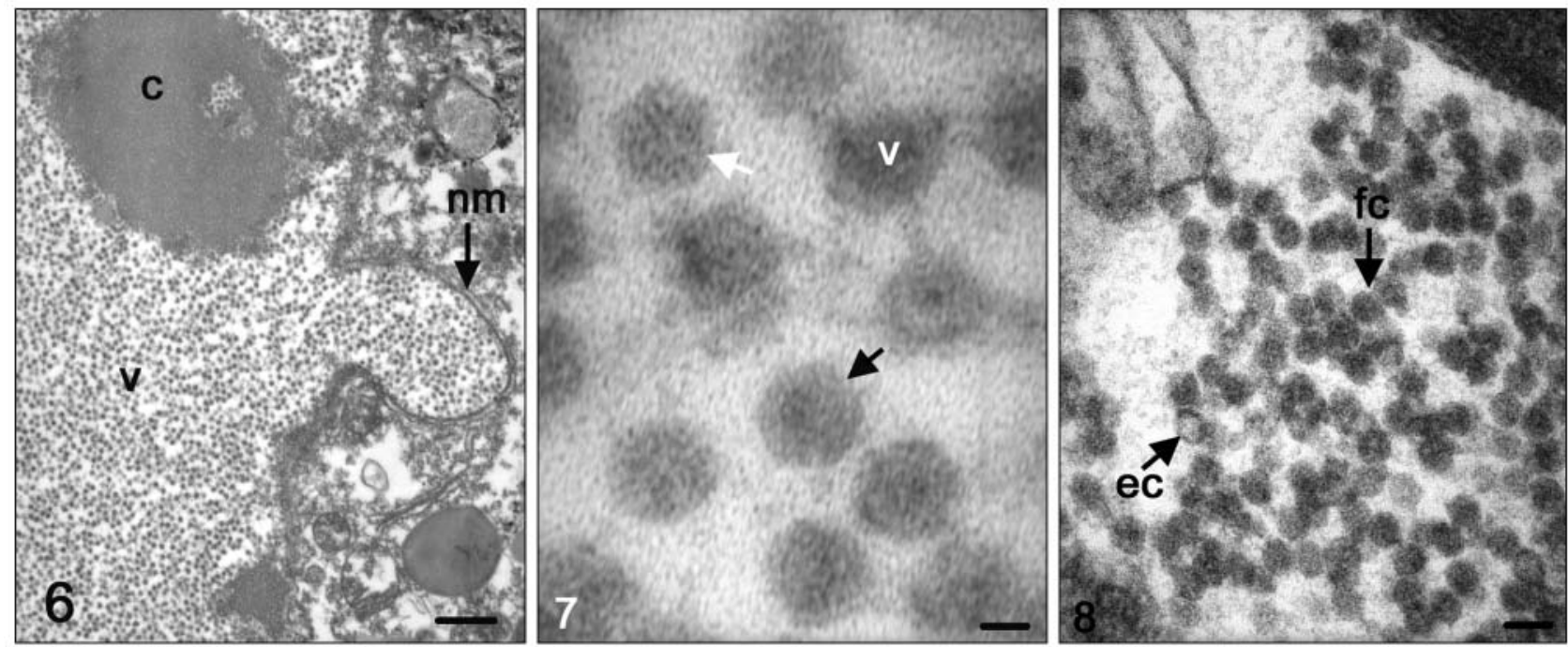

Figs. 6 to 8. Crassostrea gigas. Intranuclear viral particles in oyster gamete. Ultrathin sections of the gonadal tissue. Fig. 6. Intranuclear viral particles (v) in an ovocyte with a normal nuclear membrane (nm) and chromatin masses (c); scale bar $=500 \mathrm{~nm}$. Fig. 7. Intranuclear 5-sided (white arrow) and 6-sided (black arrow) viral particles (v) in a spermatozoa; scale bar $=20 \mathrm{~nm}$. Fig. 8. Intranuclear viral particles in an ovocyte. Presence of empty (ec) and full capsids (fc); scale bar $=50 \mathrm{~nm}$

the viral infection varied between 3.3 and $13.3 \%$ (Table 1). Gonad lesions were observed in Crassostrea gigas in several production areas (Fig. 1) mainly during summer when gonad maturation is maximum; however, viral particles were also found in 2 occurrences in winter in the early stages of gametogenesis, ovogonia or spermatogonia from non-mature

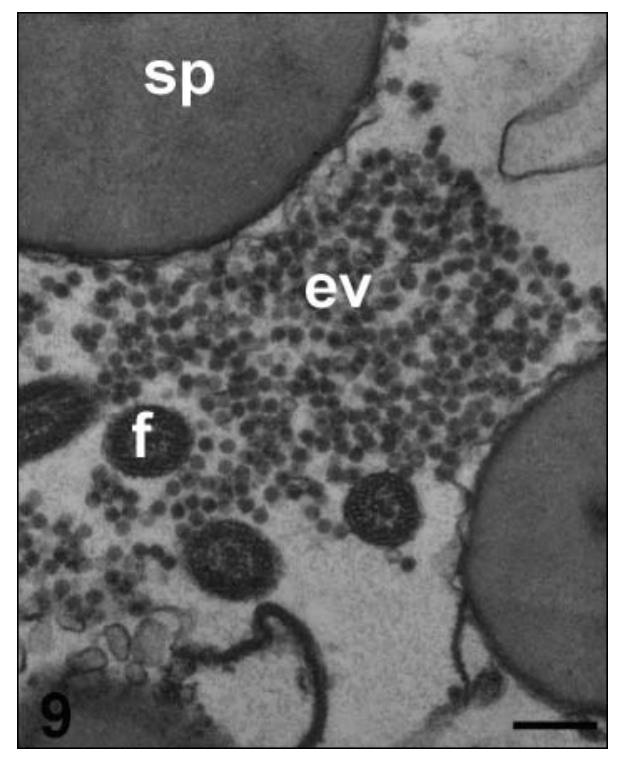

Fig. 9. Crassostrea gigas. Extracellular viral particles in gonad follicles of the oyster. Ultrathin section of the gonadal tissue. Extracellular viral particles (ev) between sperm flagella (f) and spermatozoa (sp) section; scale bar $=200 \mathrm{~nm}$ individuals. VGH infected spat and adults in males, females, hermaphrodites and individuals in the early stages of gametogenesis (Fig. 10, Table 1). In one of the 2 infected hermaphrodite individuals, which were predominantly male, only the ovocytes were infected whereas in the other hermaphrodite individual, both ovocytes and spermatozoa were infected. No significant difference at the $5 \%$ significance level was noted in the infection frequency between males and females during the years 2002 to $2004\left(\chi^{2}=1.22\right.$; $\mathrm{p}=0.27$ ).

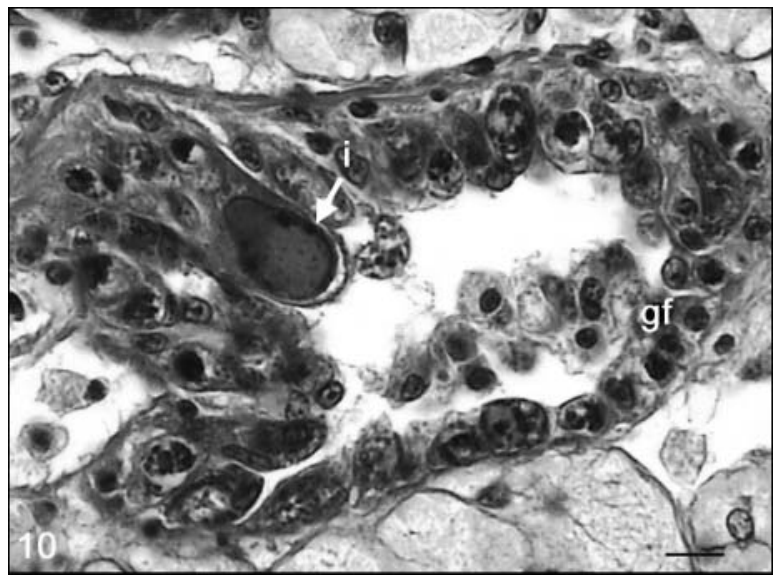

Fig. 10. Crassostrea gigas. Intranuclear inclusion in a gonad follicle of the oyster. Histological section in the gonadal tissue stained with hematoxylin-eosin (scale bar $=10 \mu \mathrm{m}$ ). Intranuclear inclusion (i) in a gonad follicle (gf) at the early stages of gametogenesis 


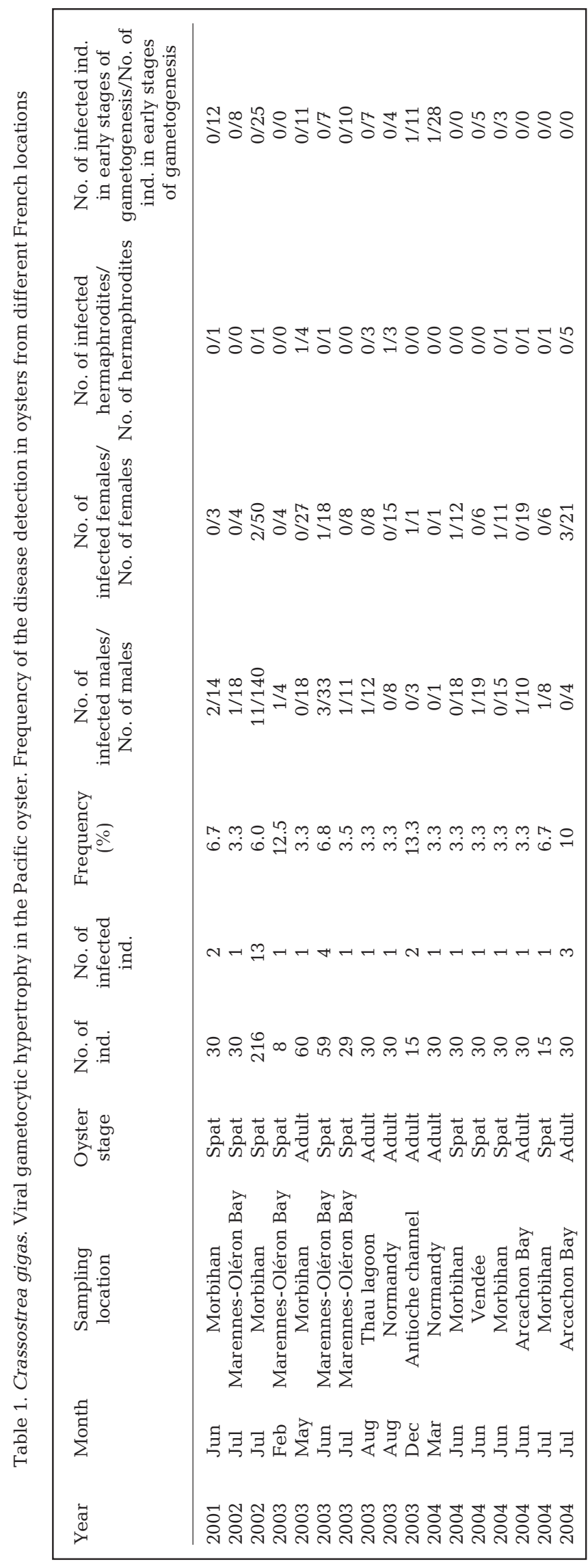

\section{DISCUSSION}

Farley (1976) was the first author to report gametocyte hypertrophy associated with papilloma-like viruses in marine bivalves. Since then, similar conditions have been detected and reported from different oysters in North America and Asia (McGladdery \& Stephenson 1994, Elston 1997, Choi et al. 2004). This report is the first record of gametocytic hypertrophy in Crassostrea gigas in Europe.

Ultrastructural observations have shown that, as previously reported, lesions detected in histology are associated with the presence of viral particles. The morphological characteristics displayed by these viral particles, including size and capsid symmetry, strongly suggest their close relationship with the families Papillomaviridae and Polyomaviridae (Van Regenmortel et al. 2000). Unlike viral particles previously described in Crassostrea virginica (McGladdery \& Stephenson 1994, Farley 1985) and in C. gigas (Choi et al. 2004), the viral particles described in our study cannot be formally assigned to one of these families.

Papilloma-like and polyoma-like viruses have already been described from several bivalve species in different organs and tissues (Elston 1997). All cases were reported as inducing massive hypertrophy of infected cell nuclei associated with nuclear inclusions. Neither histopathology nor ultrastructure studies allow discrimination of these viral particles that were reported from different host species in different part of the world. The question of whether one or more types of virus are responsible for these infections remains open.

The frequency of VGH in Crassostrea gigas reported in this study (3.3 to $13.3 \%$ ) is similar to those previously observed but slightly below the frequency for C. virginica in the USA (1 to $30 \%$; Farley 1985, Winstead \& Courtney 2003) and slightly above that for C. gigas in Korea (3.3 to $7.1 \%$; Choi et al. 2004). These differences may not be significant. The infection intensity of the disease in French populations of C. gigas was usually low (up to 136 infected cells per section) compared to the maximum infection reported in C. virginica (up to 350 infected cells; Farley 1985). However, the overall infection intensity (16 infected cells per section on average) was higher in the present study compared to that reported in C. virginica (4 infected cells per section on average; Farley 1985). The 2 species of cupped oysters are well known for displaying clear differential lesions in response to parasitic infections. VGH equally affected Crassostrea gigas males and females, unlike $C$. virginica, in which females were more often reported infected (Farley 1985).

The low recorded frequency and intensity of this condition suggest that VGH probably has no lethal impact on oysters. This assertion is also supported by 
the absence of a haemocytic reaction, as was similarly observed in Crassostrea gigas in Korea (Choi et al. 2004). However, although VGH has no or limited impact at population levels, the virus may affect the viability of oyster gametes and consequently oyster fecundity, as has been proposed for other pathogens affecting gametes such as Steinhausia spp. in Mytilus galloprovincialis (Figueras et al. 1991) or Marteilioides chungmuensis in C. gigas (Park et al. 1998). The viral particles in our study were also observed in an extracellular location within the gonad follicles of C. gigas, as was also the case in $C$. virginica (Farley 1985). This extracellular presence in the gonad follicle strongly suggests a potential for vertical transmission of the virus as well as horizontal transmission to progeny during the spawning process. Vertical transmission is proposed for oyster herpesvirus (Arzul et al. 2002) and also for human Papillomavirus and Polyomavirus (Pietropaolo et al. 1998, Tenti et al. 1999).

Although the impact of VGH on Crassostrea gigas populations and stocks seems to be limited, caution should be taken with regards to the oncogenic capacity of many other members of the Papillomaviridae and Polyomaviridae families (Van Regenmortel et al. 2000). For example, in Mya arenaria, such viruses were also suspected in gonadal neoplasia of the soft-shell clam (Harshbarger et al. 1979). Beyond their potential pathogenic impact, these viruses may open new avenues in the development of molluscan cell lines. The study of an oncogenic virus could bring new impetus to the development of cell lines, as some authors proposed with human Papillomaviruses for the immortalization of cell lines (Oda et al. 1996).

$\mathrm{VGH}$ is readily detected during the later stages of gametogenesis, suggesting an underestimation of the infection rates in the early stages of gametogenesis or after gamete release. In France, the number of infected individuals, as well as the distribution area, has apparently increased between 2001 and 2004, but the frequency at a given site remained low. Despite an intensive survey of Pacific oyster populations in France (between 1990 and 2004, a total of 43418 oysters were analysed by the National Network for Surveillance and Monitoring of Mollusc Health, REPAMO), VGH had never been reported before 2001, suggesting a possible recent emergence of the disease. However, both low frequency and low intensity of the infection associated with the difficulty of detection from non-mature stages could also explain why it has only recently been detected. It is usually accepted that once a condition is described, it will then be increasingly recognised and recorded by diagnosticians; such a process may explain an apparent increase in the prevalence of VGH in French stocks. Since drafting of this manuscript, 7 cases were recorded by the REPAMO network in 2004, which shows a relatively stable number of cases detected annually. However, with 2 cases reported from Arcachon Bay and Vendée in 2004, sites where VGH had not previously been detected, the distribution area of this virus appears to be increasing. This increase could possibly be explained by transfers between the different production areas; the lower frequency of transfers in Arcachon Bay and Vendée than in other production areas, such as Marennes-Oléron Bay, Brittany and Normandy, could explain the late appearance of VGH in these areas. Therefore, VGH is currently flagged by the REPAMO network as a potential concern and a series of 3 measures are being undertaken: (1) communication with European counterparts within the existing network of the National Reference Laboratories for Mollusc Diseases; (2) implementation of a targeted survey to assess the potential spread and impact of $\mathrm{VGH}_{\text {; }}$ and (3) retrospective analysis of archived material to assess the most probable status of oyster populations prior to initial recognition in 2001.

Acknowledgements. We thank the coastal correspondents of the REPAMO network for their contribution in collecting and providing samples and related information. The authors acknowledge T. Renault for his technical advice on electron microscopy. This work was supported by the EU Community Reference Laboratory for Mollusc Diseases, IFREMER, La Tremblade, France.

\section{LITERATURE CITED}

Ancelle T (2002) Statistique épidémiologie. Maloine, Paris

Arzul I, Renault T, Thébault A, Gérard A (2002) Detection of oyster herpesvirus DNA and proteins in asymptomatic Crassostrea gigas adults. Virus Res 84:151-160

Bozzo MG, Ribes E, Sagrista E, Poquet M, Durfort M (1993) Fine structure of the spermatozoa of Crassostrea gigas (Mollusca, Bivalvia). Mol Reprod Dev 34:206-211

Bower SM, McGladdery SE, Price IM (1994) Synopsis of infectious diseases and parasites of commercially exploited shellfish. Annu Rev Fish Dis 4:1-99

Choi DL, Lee NS, Choi HJ, Park MA, McGladdery SE, Park MS (2004) Viral gametocytic hypertrophy caused by a papova-like virus infection in the Pacific oyster Crassostrea gigas in Korea. Dis Aquat Org 59:205-209

Edwards MR, Samsonoff WA, Kuzia EJ (1977) Papilloma-like viruses from catfish. Fish Health News 6:94-95

Elston R (1997) Special topic review: bivalve mollusc viruses. World J Microbiol Biotechnol 13:393-403

Farley CA (1976) Ultrastructural observations on epizootic neoplasia and lytic virus infection in bivalve mollusks. Prog Exp Tumor Res 20:283-294

Farley CA (1978) Viruses and viruslike lesions in marine mollusks. Mar Fish Rev 40:18-20

Farley CA (1985) Viral gametocyte hypertrophy in oysters. In: Sindermann CJ (ed) Identification leaflets for diseases and parasites of fish and shellfish, No 25. ICES, Copenhagen, p 5

Figueras AJ, Jardon CF, Caldas JR (1991) Diseases and parasites of rafted mussels (Mytilus galloprovincialis Lmk): preliminary results. Aquaculture 99:17-33 
Harshbarger JC, Otto SV, Chang SC (1979) Proliferative disorders in Crassostrea virginica and Mya arenaria from the Chesapeake Bay and intranuclear virus-like inclusions in Mya arenaria with germinomas from a Maine oil spill site. Haliotis 8:243-248

Lango-Reynoso F, Chavez-Villalba J, Cochard JC, Le Pennec M (2000) Ovocyte size, a means to evaluate the gametogenic development of the Pacific oyster, Crassostrea gigas (Thunberg). Aquaculture 190:183-199

McGladdery SE, Stephenson MF (1994) A viral infection of the gonads of eastern oyster (Crassostrea virginica) from Atlantic Canada. Bull Aquac Assoc Can 94:84-86

Montes JF, Durfort M, Garcia-Valero J (2001) Parasitism by the protozoan Perkinsus atlanticus favours the development of opportunistic infections. Dis Aquat Org 46:57-66

Oda D, Bigler L, Lee P, Blanton R (1996) HPV immortalization of human oral epithelial cells: a model for carcinogenesis. Exp Cell Res 226:164-169

Park MS, Lyu HY, Lee TS (1998) Investigation on the cause of bad natural seed collection of the Pacific oyster, Crassostrea gigas: relationships between the conditions of mother shell and the viability of the released eggs and lar-

Editorial responsibility: Albert K. Sparks, Seattle, Washington, USA vae based on the pathological and embryological survey. J Korean Fish Soc 32:62-67

Pietropaolo V, Di Taranto C, Degener AM, Jin L, Sinibaldi L, Baiocchini A, Melis M, Orsi N (1998) Transplacental transmission of human Polyomavirus BK. J Med Virol 56: 372-376

Scherrer B (1984) Biostatistique. Gaëtan Morin Editeur, Chicoutimi

Sparks AK (1985) Synopsis of invertebrate pathology exclusive insects. Elsevier Science Publishers, Amsterdam

Tenti P, Zappatore R, Migliora P, Spinillo A, Belloni C, Carnevali L (1999) Perinatal transmission of human Papillomavirus from gravidas with latent infections. Obstet Gynecol 93:475-479

Van Regenmortel HV, Fauquet CM, Bishop DHL, Carstens EB and 7 others (2000) Virus taxonomy: classification and nomenclature of viruses. Seventh report of the International Committee on Taxonomy of Viruses. Academic Press, San Diego, CA, 241-251

Winstead JT, Courtney LA (2003) Ovacystis-like condition in the eastern oyster Crassostrea virginica from the northeastern Gulf of Mexico. Dis Aquat Org 53:89-90

Submitted: April 9, 2005; Accepted: January 23, 2006

Proofs received from author(s): May 23, 2006 